\title{
MODEL INTERVENSI NEGARA PADA NAGARI DI SUMATERA BARAT: SEBUAH ANALISIS PEMECAHAN MASALAH DENGAN MENGGUNAKAN PENDEKATAN ELITE DAN DISTRIBUSI KEKUASAAN
}

\author{
Tengku Rika Valentina² dan Roni Ekha Putera ${ }^{3}$ \\ ${ }^{2}$ Jurusan Ilmu Politik dan ${ }^{3}$ Program Studi Ilmu Administrasi Negara \\ Fakultas Ilmu Sosial dan Ilmu Politik Universitas Andalas, Padang, Indonesia \\ Email:tengkurika@fisip.unand.ac.id dan roniekhaputera@fisip.unand.ac.id
}

\begin{abstract}
ABSTRAK. Ada eforia yang terjadi ketika gerakan kembali ke-nagari di Sumatera Barat menjadi terasa berlebihan, karena masyarakat Minangkabau seperti punya keinginan terciptanya kembali nagari tradisonal seperti pada masa dulunya, padahal dalam prakteknya sangat bertolak belakang. Nagari sekarang sengaja diformat oleh Negara ( baca: pemerintah daerah) dengan perubahan yang sangat substansi pada fungsi dan peran lembaga yang ada dalam nagari. Konsekuensinya nagari sebagai institusi lembaga formal pada tingkat lokal tidak lagi sepenuhnya otonom, banyak konflik yang menyertai perjalanannya, dengan segala kompleksitasnya sebenarnya sangat menarik untuk dijadikan sebagai bahan kajian diskusi yang dikupas dalam bentuk hasil penelitian karena antara Negara (baca: pemerintah daerah) dengan nagari terselip keinginan untuk men-setting nagari dengan format yang berbeda, sehingga ada sebuah solusi yang penulis tawarkan untuk menjembatani dua perbedaan tersebut yang penulis uraikan dalam bentuk model analisis pendekatan elite dan distribusi kekuasaan. Penelitian ini dilakukan secara kualitatif dengan metode Grounded Theory, mengambil analisis kasus pada satu nagari sebagai representasi dari ratusan nagari yang ada di Sumatera Barat, informan dalam penelitian ini adalah elite nagari yang dipilih berdasarkan kriteria yang sudah ditetapkan sebelumnya. Hasil dari penelitian ini ada sebuah solusi yang menarik yang penulis tawarkan kepada pemerintah daerah dan nagari bagaimana cara "positif" menyalurkan opini publik masyarakat nagari sehingga tidak terjadi "perang kepentingan"dalam memetakan format sebuah nagari, dengan menggunakan analisis dasar pendekatan elite dan distribusi kekuasaan dan adopsi model bendungan menurut Jurgen Habermas dalam menata sebuah ruang publik.

Kata kunci: Nagari, Pemerintahan Nagari, Intervensi Negara, Ruang Publik
\end{abstract}

\section{STATE INTERVENTION MODEL IN THE WEST SUMATERA NAGARI: An Analysis of Problem Solving Using Elite Approach and Power Distribution}

\begin{abstract}
There is a euphoria that occurs when the return to villages in West Sumatera feels redundant, because people have the desire to create Minangkabau as back as in the traditional villages. Yet in practice it is very contradictory. Nagari now accidentally formatted by the State (read: government) to change the very substance of the functions and the role of institutions in the villages. Consequently nagari as the institution of formal institutions at the local level is no longer fully autonomous, many conflicts that accompany the journey, with all its complexity is actually very interesting to be used as study materials are removed in the form of discussion of research results because the State (read: government) with villages tucked desire for settings to villages with different formats, so there is a solution to bridge the two difference researchers described in the form of a model approach to the analysis and distribution of power elite. By using qualitative research was conducted by the method of Grounded Theory, taking on the case analysis of the hundreds of villages as a representation of existing villages in West Sumatra, informants in this study were selected based elite nagari predefined criteria. The results of this study there is an attractive solution that researchers have to offer to the local governments and villages how to "positive" public opinion channeling the villages so there is no "war of interests" in a village mapping format, using basic analytical approach elite and the distribution of power and adoption of the model dam by Jurgen Habermas in managing a public sphare.
\end{abstract}

Keywords: Nagari, Nagari Government, State Intervention, Public Sphare 


\section{PENDAHULUAN}

Gerakan "kembali ke nagari" menurut penulis dirasa terlalu berlebihan ketika yang terjadi pada saat sekarang ini masyarakat mengimpikan terciptanya kembali (recreating) seperti "republik kecil" di zaman dulu. Tetapi dalam prakteknya berdasarkan hasil temuan penelitian ${ }^{1}$, format nagari sekarang telah berubah mengikuti pemikiran, semangat dan perubahan baru; dan yang lebih penting nagari "diatur" oleh Provinsi dan Kabupaten. Konsekuensinya, nagari tidak sepenuhnya otonom, melainkan harus mengikuti regulasi yang dibuat oleh negara.

Kalau dilihat berdasarkan logika tradisionalnya Max Weber (1946), negara, penulis asumsikan sebagai pemerintah daerah dan didefinisikan sebagai sebuah komunitas manusia yang berhasil mengklaim monopoli penggunaan yang sah atas kekuasaan fisik dalam sebuah teritori tertentu². Oleh karena itu, menurut asumsi penulis untuk sampai pada implementasi model elite dan distribusi kekuasaan ketika negara menerapkan intervensinya pada pemerintahan nagari, penulis mencoba menawarkan dalam pembahasan untuk melihat aktivitas negara terlebih dahulu (baca: Pemerintah daerah) dengan menyorot fungsi, tujuan dan kekuatan dari negara (baca: Pemerintah daerah) dan kemampuan negara (baca: Pemerintah daerah) dalam menjalankan kebijakan yang ada.

Berdasarkan penjelasan di atas dengan segala kompleksitasnya cukup menarik sebenarnya dijadikan sebagai kajian dan bahan penelitian dalam menemukan menemukan analisis pemecahan masalah bagi negara dan pemerintahan nagari ketika ada sebuah makna "intervensi" dalam hal kewenangan. sehingga setting lembaga nagari pada akhirnya diformat oleh negara. Permasalahan di atas kemudian dirumuskan dalam pertanyaan kunci dengan menggunakan model elite dan distribusi kekuasaan yaitu bagaimana bentuk analisis pemecahan masalah ketika negara menerapkan intervensinya pada lembaga pemerintahan nagari.

Sebagai pijakan dasar, konsep yang penulis pakai adalah menggunakan penelitiannya Tengku Rika dkk tentang The state Versus Local Elite Conflict in A Transitional Phase of Democracy. yang di publikasikan dalam International Journal of Administrative Sciences and Organization ${ }^{3}$. Tengku Rika dkk mendeskripsikan ketika hendak menguraikan akar konflik dalam praktek desentralisasi dan pelimpahan kewenangan yang diberikan oleh negara kepada nagari, ternyata nagari sudah "dibingkai sedemikan rupa" oleh negara (baca: pemerintah propinsi dan pemerintah kabupaten) dalam menjalankan kewenangannya tanpa memperhatikan lagi makna asal usul budaya dan karakeristik masyarakat sesuai yang sudah diamanatkan dalam UndangUndang No. 32 Tahun 2004 tentang pemerintah daerah $^{4}$.

Penjelasan tentang negara yang berperan sebagai aktor yang mengintervensi pada nagari menjadi hal yang membedakan dari analisis ini, dimana penulis memfokuskan pada bentuk intervensi negara dengan memakai konstruksi teorinya Alexis de Tocqueville tentang demokrasi ${ }^{5}$, dimana demokrasi adalah cara atau seni pergaulan hidup untuk mencapai kebaikan bersama. Gagasan ini merupakan alternatif terhadap gagasan arus-utama yang mengartikan demokrasi sebagai pemerintahan atau kedaulatan rakyat serta demokrasi adalah proses pembelajaran dan kelembagaan yang menghubungkan lembaga- lembaga politik formal (suprastruktur politik) dengan kehidupan politik sehari- hari dalam masyarakat (infrastruktur politik) sehingga ketika sampai pada analisis inti Bagaimana negara dan nagari didefenisiskan dan dibingkai dengan segala kompleksitas kewenangannnya, dengan menggunakan analisis teori dan model sirkulasi opini publik menurut Habermas $^{6}$ menjadi sangat kaya akan berbagai ide untuk mencari solusi permasalahan dalam penelitian ini. Adapun tujuan dari penelitian dalam artikel ini penulis ingin memberikan eksplanasi dan interprestasi dan analisis yang lebih tajam terhadap penggunaan model elite dan distribusi kekuasaan pada pemerintahan nagari ketika negara menerapkan pola intervensi pada nagari dengan mengambil satu nagari sebagai objek penelitian. Sehingga nantinya model yang akan dibuat akan bermanfaat pada pemerintah daerah yang lain diluar Sumatera Barat untuk mengalokasikan kekuasaannya pada pemerintah bawah, karena pada prinsipnya nagari sebagai unit pemerintahan terendah sama bentuk kerja administrasinya dengan pemerintahan desa/ kelurahan.

\section{METODE}

Penelitian ini Penulis menggunakan metode kualitatif secara Grounded theory, dimana Metode 
grounded theory dirancang sebagai alat bantu bagi peneliti agar dapat memproduksi teori secara konseptual dan sifatnya sangat padat. Hubungan tersebut dipaparkan sebagai proposisi sebagaimana didalam penelitian kualitatif lainnya melalui sebuah tulisan yang bersifat deskriptif dan konseptual dengan mengambil salah satu lokus nagari yang akan dianalisis yaitu nagari Panyakalan.

Untuk memberi penjelasan yang rinci terhadap masalah yang diteliti, perlu dikumpulkan data dari berbagai sumber. Data primer direncanakan diperoleh dari wawancara mendalam (indepth interview) dengan pihak-pihak terkait ${ }^{8}$. Selain itu untuk membantu menjelaskan masalah yang diteliti, penelitian ini juga mengunakan sumber tertulis (data sekunder) seperti sumber dari arsip, dokumen pribadi, dokumen resmi, majalah ilmiah, dan seterusnya.

Unit analsis yang digunakan dalam penelitian ini adalah lembaga, dimana lebih difokuskan pada pemerintah daerah sebagai aktor dari negara dan pemerintah nagari sebagai elite lokal. Untuk pengambilan informan dalam penelitian ini digunakan teknik purposive sampling sesuai dengan kriteria jabatan dari elite nagari.

Sedangkan data yang diperoleh dianalisis sesuai dengan prinsip metode Grounded Theory Disamping perolehan data dari pelaporan "on the spot", data yang banyak tersebut juga harus direduksi dengan jalan membuat abstraksi sebagai sebuah rangkuman yang inti. Di sini akan dilakukan pengembangan teori dan hubungan antara variabel di dalam teori, serta juga nantinya akan berhubungan dengan kedalaman analisa dan menalaah data secara sistematis. Hubungan tersebut dipaparkan sebagai proposisi sebagaimana didalam penelitian kualitatif lainnya melalui sebuah tulisan yang bersifat deskriptif dan konseptual Analisis dilakukan berdasarkan pandangan-pandangan informan (emik) yang sudah di validasi dengan menggunakan metode triangulasi. Kesimpulan dari analisis yang dilakukan terkait pada gabungan data yang didapat dari informan (emik) dan interpretasi peneliti (etic) terhadap data lapangan tersebut.

\section{HASIL DAN PEMBAHASAN.}

\section{Sirkulasi Opini Publik Di Nagari Panyakalan}

Selama lebih dari satu dasawarsa, geliat reformasi telah bergerak menuntaskan agenda pembenahan sistem politik di Indonesia, penegakan sistem politik tersebut salah satunya adalah penegakan kembali prinsip-prinsip demokrasi terutama demokrasi pada tingkatan lokal yang selama ini terabaikan. Berdasarkan antithesis dari fenomena tersebut, dalam penelitian ini fokus yang ingin dianalisis adalah berbagai perubahan sturktural pemaknaan prinsip demokrasi yang terjadi pada tingkatan lokal (nagari). salah satu perubahan tersebut adalah terselenggaranya salah satu bentuk pelaksanaan dari prinsip demokrasi yaitu pemilihan langsung pemimpin nagari ${ }^{9}$. Menurut asumsi penulis pemilihan langsung pemimpin sebuah lembaga lokal (nagari) menjadi titik balik kedaulatan sistem politik di Sumatera Barat. Suara masyarakat nagari pada akhirnya harus dihitung sebagai variabel utama dalam meneguhkan legitimasi kepemimpinan publik. Demokrasi pada tingkatan lokal secara tidak langsung memberikan sebuah paradigma yang tegas bahwa proses setiap penyelenggaraan kebijakan dan pembangunan dalam nagari harus melibatkan seluruh komponen masyarakat.

Dari asumsi di atas dengan menggunakan metode grounded theory penulis mencoba merefleksikan kembali sebuah makna demokrasi lokal pembentuk sistem politik dalam nagari yang secara tidak langsung diskursus tentang ini menjadi analisis pembuka pada dinamika sistem politik di Nagari Panyakalan. Pendapat dari Tocqueville mengambarkan sebuah paradigma partisipasi masyarakat, dari hasil data yang didapat pada penelitian lapangan dengan segala bentuk komplesitas permasalahan yang dihadapi di nagari ${ }^{10}$ penulis menyajikan sebuah maping sistem politik baru pada Nagari Panyakalan dengan menggabungkan pendapatnya Tocqueville dengan teorinya Jurgen Habermas tentang demokrasi deliberatif (demokrasi permusyawaratan ${ }^{11}$ dengan teori diskursus dan ruang publik (public sphare) ${ }^{12}$ yang berwujud dalam bentuk penyebaran kekuasaan yang sering dipermasalahkan antara elite dan pengambil keputusan dalam nagari serta dengan negara ( baca: Pemerintah Kabupaten Solok) seperti yang terlihat pada gambar 1 berikut ini: 


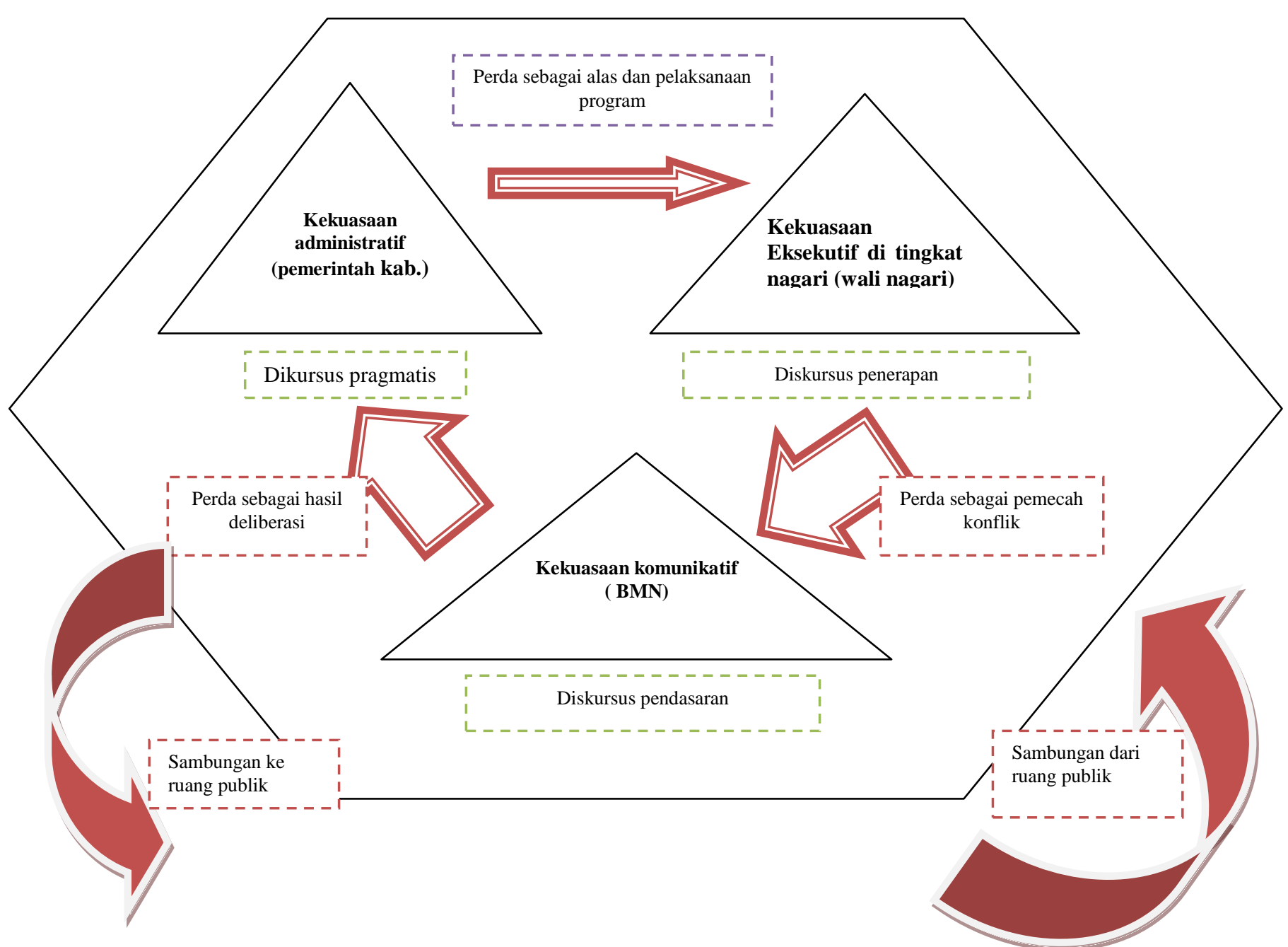

Gambar 1. Maping Pembagian Kekuasaan Pada Nagari Panyakalan Dan Solusi Permasalahannya Dengan Mengadopsi Teorinya Jurgen Habermas ${ }^{13}$

Berdasarkan gambar 1 secara prinsip kekuasaan sebuah pemerintah nagari dan wali nagari terikat pada peraturan daerah, instruksi bupati dalam bentuk tupoksi dan kewenangan. Pada prinsipnya segala bentuk aturan tersebut akan meminimalisasi lahirnya sebuah kebijakan yang sifatnyan tumpang tindih, sehingga intinya negara (baca: pemerintah daerah) mempunyai kekuatan "memaksa" untuk menerapkan segala bentuk aturannya.

Penulis mencoba membuat sebuah asumsi, inti dari kewenangan antara wali nagari, BMN (Badan Musyawarah Nagari), dan KAN (Kerapatan Adat Nagari) sebagai sebuah konsep Trias politika sangat "rentan" disalahgunakan oleh para elite nagari ${ }^{14}$ yang berada didalamnya, yang selalu mengeluarkan keputusan atas nama "kepentingan masyarakat nagari", seperti misalnya "... Melaksanakan peraturan nagari (pernag) yang telah ditetapkan bersama BMN..."15. ditambah lagi di Nagari Panyakalan tidak satupun peraturan nagari dilahirkan untuk mendukung pelayanan kepada masyarakat, pada hal salah satu fungsi Wali Nagari adalah melaksanakan Peraturan nagari yang ditetapkan oleh BMN. Wali nagari selaku eksekutif dalam nagari dan BMN berdalih aturan tersebut sudah dituangkan dalan bentuk instruksi wali nagari ${ }^{16}$ atau aturan yang telah dikeluarkan oleh Pemerintah Daerah. Sehingga hipotesis penulis, 
masyarakat tidak memiliki celah untuk melakukan delegitimasi sebuah aturan yang dibuat oleh pemerintah nagari dalam bentuk pernag (peraturan nagari) dan instruksi wali nagari. Berdasarkan masalah diatas dengan segala kompleksitasnya penulis menawarkan gagasan yang dibawa oleh Habermas yang dinamakan sebagai ruang publik.

Sekarang pertanyaan kita dimana tempat ruang publik tersebut "berada"? berdasarkan analisa penulis dari data hasil penelitian dan mengkomparasikannya dengan analisis sirkulasi Opini Publiknya Jurgen Habermas ${ }^{17}$, seharusnya BMN bukan sebagai satu satunya bentuk tempat legitimasi dan aspirasi masyarakat nagari yang sah dan KAN bisa dimanfaatkan sebagai bentuk ruang publik bagi masyarakat nagari ${ }^{18}$, KAN bisa dijadikan sebagai sebagai ruang publik tempat masyarakat nagari dari berbagai suku berkomunikasi dan membangun opini mereka. Jadi menurut penulis, institusi KAN dalam nagari seharusnya bisa dimoderenisasi, dimana tidak hanya mengurus kepentingan anak kemenakan dan sako pusako (harta pusaka) saja tetapi bisa menjembatani kepentingan masyarakat nagari dengan pemerintah nagari Panyakalan.

Ada temuan yang menarik dari hasil penelitian ini, dimana penulis melihat, bahwa institusi KAN di Nagari Panyakalan sifatnya lebih independen dengan pemerintah nagari, dimana dalam pembentukannya KAN dalam nagari dipilih oleh ninik mamak (penghulu) dalam nagari tersebut dan diangkat oleh pengurus mereka sendiri tanpa turut campur oleh pemerintah kabupaten dan pemerintah nagari ${ }^{19}$. Jadi konsep ruang publik menurut Habermas semakin kuat menurut penulis dilekatkan kepada KAN karena sejatinya hubungan masyarakat nagari dengan BMN sebagai institusi lembaga legislatif bukanlah relasi yang liniear, dia hanya sebagai kekuasaan yang sifatnya pemberian mandat oleh masyarakat nagari dengan wakilnya yang duduk dalam BMN, dan KAN diakui keberadaannya secara politik dalam nagari dan sirkulasi opini publik dalam nagari tidak hanya berjalan satu arah dengan BMN saja tetapi juga bisa memanfaatkan sebagai ruang publik yang sifatnya lebih independen. Penulis mencoba menawarkan sebuah model sirkulasi opini publik dari bagan sistem politik diatas dengan mengadopsi model bendungan Habermas tentang sirkulasi opini publik dalam proses deliberasi, dan memandang negara hukum yang demokratis sebagai representasi pusat dan pinggiran dan ada komunikasi dua jalur dalam demokrasi deliberatif (Hardiman. 2009: 149) ${ }^{20}$ dan penulis adopsi untuk melihat representasi pusat (penduduk asli) dengan pinggiran (masyarakat pendatang) dengan memanfaatkan lembaga independen dalam nagari untuk mengakomodasi kepentingan seluruh komponen masyarakat di Nagari Panyakalan, seperti yang terlihat pada gambar 2 .

Berdasarkan gambar 2, dengan memakai analisisnya Hardiman (2009: 136-141) ${ }^{21}$. Ruang publik diartikan sebagai formasi sosial dengan ciri terbuka, inklusif dan bisa diakses oleh semua orang. Jadi artinya memfungsikan KAN di nagari Panyakalan sebagai ruang publik dengan kata lain karena KAN bisa diakses oleh seluruh anak kemenakan dalam nagari. Tetapi ada sebuah celah yang timpang menurut penulis dari frasa yang dikatakan oleh Habermas dengan ruang publik politis 22 .....tindakan komunikatif yakni diskursus praktis...." seharusnya menurut asumsi penulis supaya terjalin komunikasi yang interes antara perwakilan suku di Nagari Panyakalan, dikarenakan nagari Panyakalan menganut sistem politik "lareh nan bunta" adopsi dari dua sistem politik yang ada yaitu Koto Piliang dan Bodi Chaniago ${ }^{23}$, maka model bangun komunikasi yang dibangun tetap secara oligarki (bajanjang naik batanggo turun ) dan egaliter musyawarah dan mufakat. Tujuannya Supaya esensi dari KAN walaupun institusinya dimodernisasi sesuai dengan penjelasan sebelumnya tetapi harus tetap mempertahankan sisi kearifan lokalnya. Semua aspirasi masyarakat yang selama ini hanya disalurkan dalam bentuk "ciloteh lapau nagarl'(baca: debat kusir), dalam proses selanjutnya lembaga yang ada akan memfliter segala bentuk aspirasi tersebut untuk di proses pada tingkatan yang lebih tinggi, ini untuk memungkinkan supaya tidak terjadinya tumpang tindih pelaksanaan kewenangan antara BMN dan KAN serta Wali nagari, sebelumnya aspirasi masyarakat nagari tersebut terbagi atas dua saluran, penduduk asli lebih merasa "nyaman" menyampaikan aspirasinya kepada KAN ini menurut asumsi penulis adalah sebuah representasi perwakilan suku dalam nagari, dan penduduk pendatang menyampaikan aspirasinya kepada BMN dan Wali nagari, sehingga dalam prosesnya terjadi tumpang tindih dalam urusan dan kewenangan yang berujung kepada konflik antara elite dalam pemerintahan nagari dan juga dengan pemerintah Kabupaten. 


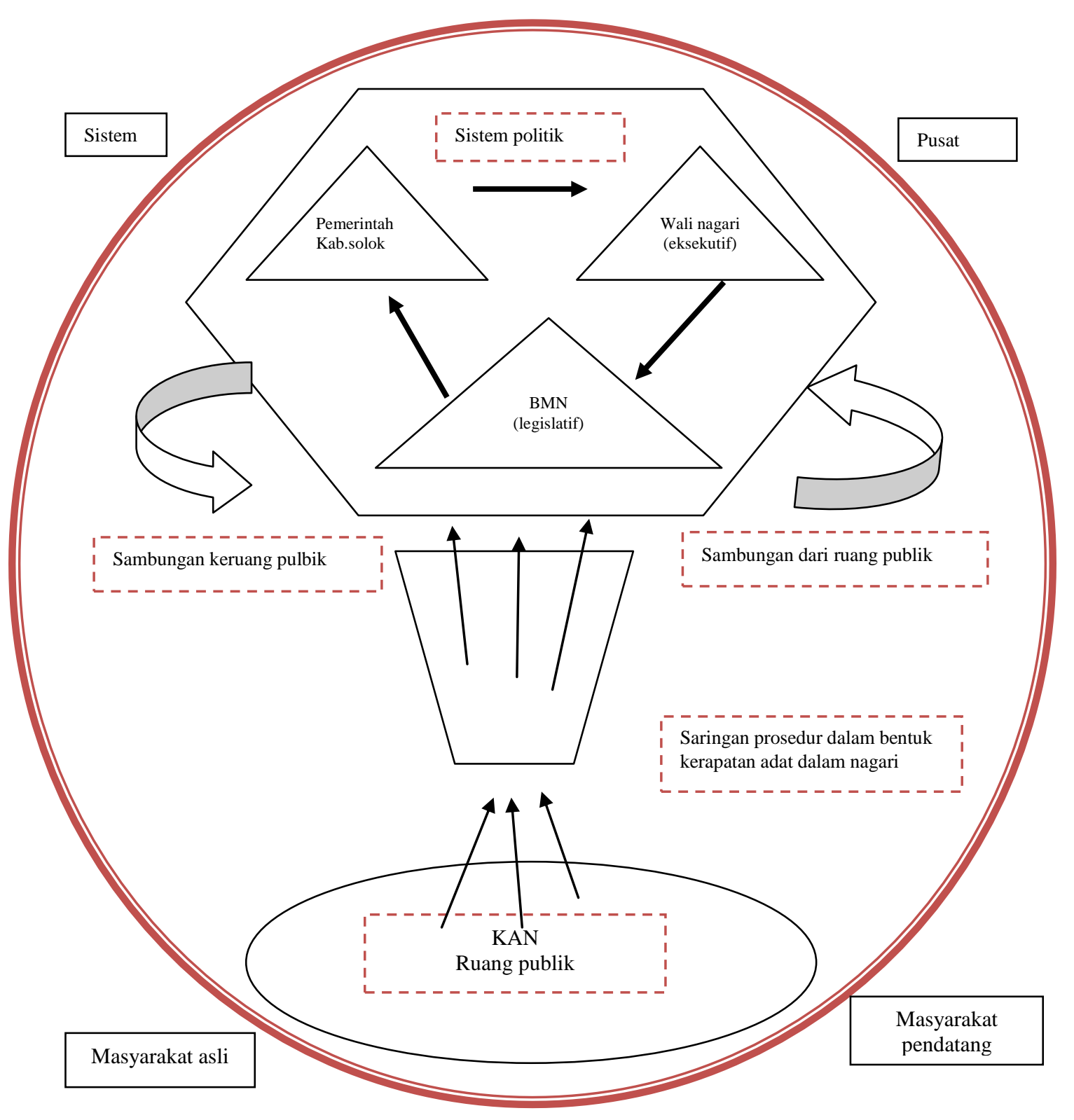

Gambar 2. Model Bendungan Habermas Yang Diadopsi Untuk Melihat Proses Sirkulasi Opini Publik Pada Masyarakat Nagari Panyakalan ${ }^{24}$

Maka adopsi model bendungan "ala" Habermas yaitu tentang sirkulasi ruang publik bisa digunakan sebagai kontrol publik terhadap tumpang tindih kewenangan antar masing masing lembaga yang ada di nagari yaitu antara Wali nagari, BMN dan KAN. Dalam kondisi seperti ini memakai pendapatnya Hardiman (2009:141) ${ }^{25}$, penulis mencoba menganalisis masalah di atas dengan memakai teorinya Habermas tentang membagi "ruang publik" menjadi dua karakter yaitu (a) ruang publik yang tidak dikooptasi dengan kekuasaan dan ruang publik yang dikooptasi dengah kekuasaan. Berarti dengan kondisi tersebut Hardiman (2009:141) mengutip ruang publik tersebut dapat "ditunggangi" oleh berbagai kepentingan. Jika elite nagari (ninik mamak, pemangku adat nagari) dalam ruang publik tersebut secara sosial mampu membangun aspirasi dari masyarakat asli dan pendatang di nagari Panyakalan maka otomatis menurut asumsi penulis ruang publik (KAN) tersebut tidak terkooptasi dengan kekuasaan dan akan terhindar dari konflik kepentingan karena sifatnya sudah "netral"26. Tetapi berbeda sebaliknya kalau 
seandainya ruang publik memisahkan aspirasi hanya dikhususkan untuk masyarakat asli (sebatas kepentingan anak kemenakan saja) dan tidak memandang masyakat pendatang sebagai satu kesatuan dengan penduduk asli maka masyarakat pendatang akan membentuk kelompok minoritas dan lama kelamaan akan menjadi sebuah kelompok yang dominan dalam lingkungan tersebut, ruang publik akan rentan dengan kooptasi kekuasaan. Karena posisi ruang publik (KAN) hanya membatasi diri untuk lingkungan kaum atau suku mereka. Inilah menurut asumsi penulis fungsi KAN hanya sekedar menjaga sako dan pusako saja dan kembali lagi ke fungsi tradisionalnya.

\section{Analisis Penggunaan Model Elite Dan Distribusi Kekuasaan Pada Nagari Panyakalan Ketika Negara (Pemerintah Kabupaten intervensinya Solok) menerapkan}

Berdasarkan data penelitian, penulis merevisi kembali model Skema Tipe Elite Dan Distribusi Kekuasaan Ketika Negara Menerapkan Intervensinya Pada Pemerintahan Terendah (UU 22 tahun 1999 Jo 32/2004 ) Merujuk Pada Teori Gaetano Mosca ${ }^{27}$ dimana penulis menambahkan dimensi ruang lingkup fungsi negara dan pengalihan skema penguatan masyarakat sipil kepada institusi KAN sebagai ruang publik yang terbuka bagi seluruh masyarakat nagari. Seperti perbandingan antara gambar 3 dengan gambar 4 .

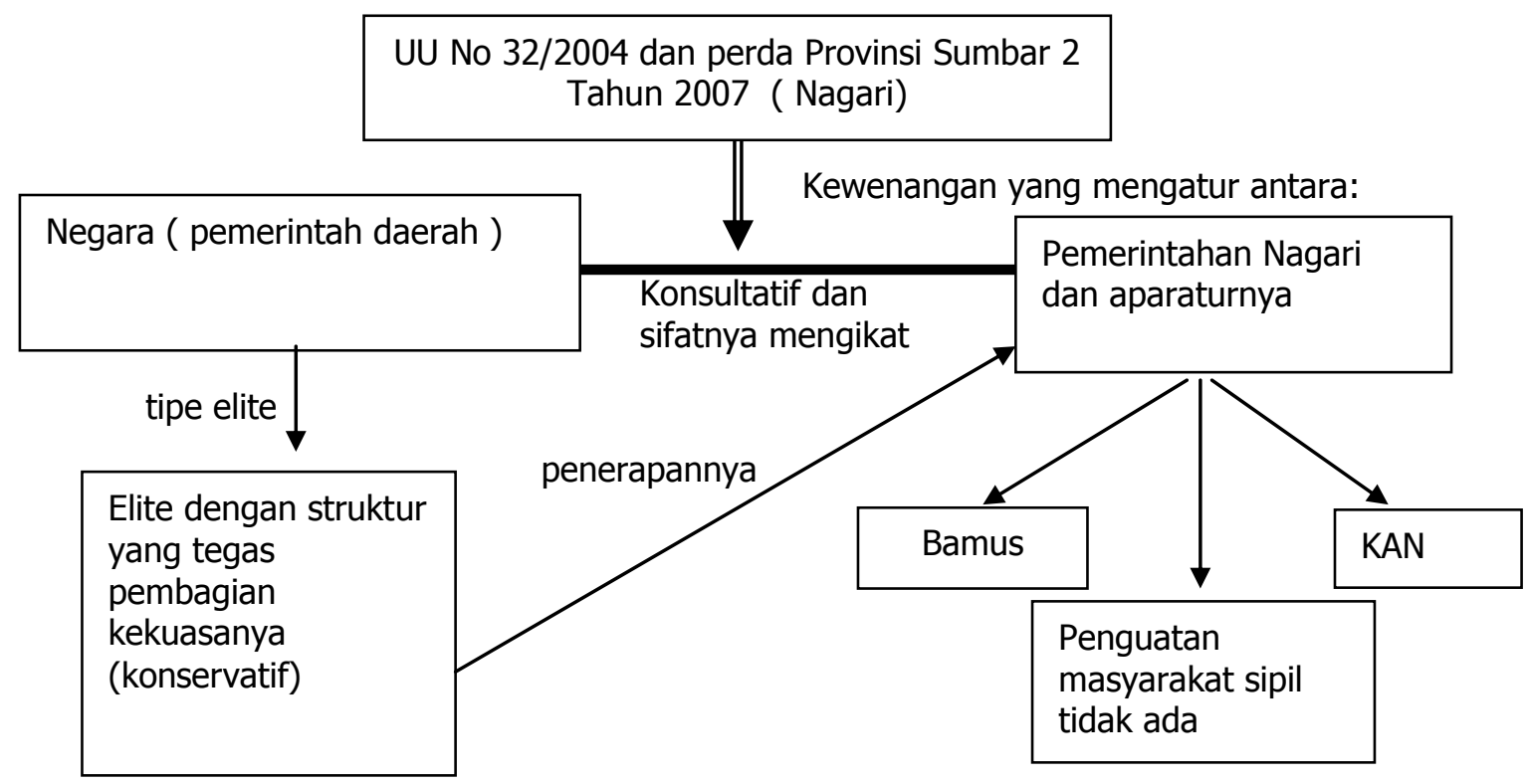

....elite politik (wali nagari dan pemerintah daerah) terdapat kesamaan nilai dan berusaha mempertahankan nilai dan mempertahankan status sebagai elite politik. Pemerintah daerah cenderung sebagai sebuah kelas yang memerintah dengan melaksanakan fungsi politik dengan memonopoli kekuasaan dan menikmati keuntungan- keuntungan dari sentralisasi kekuasaan yang dijalankan melalui jabatannya "sebagai penguasa tunggal", sehingga berdampak setiap pada proses pengambilan keputusan melalui lembaga- lembaga di tingkat nagari menjadi tidak demokratis ${ }^{28} \ldots$

Gambar 3. Skema Tipe Elite Dan Distribusi Kekuasaan Ketika Negara Menerapkan Intervensinya Pada Pemerintahan Terendah (UU 22 tahun 1999 Jo 32/2004) Merujuk Pada Teori Gaetano Mosca ${ }^{29}$ 


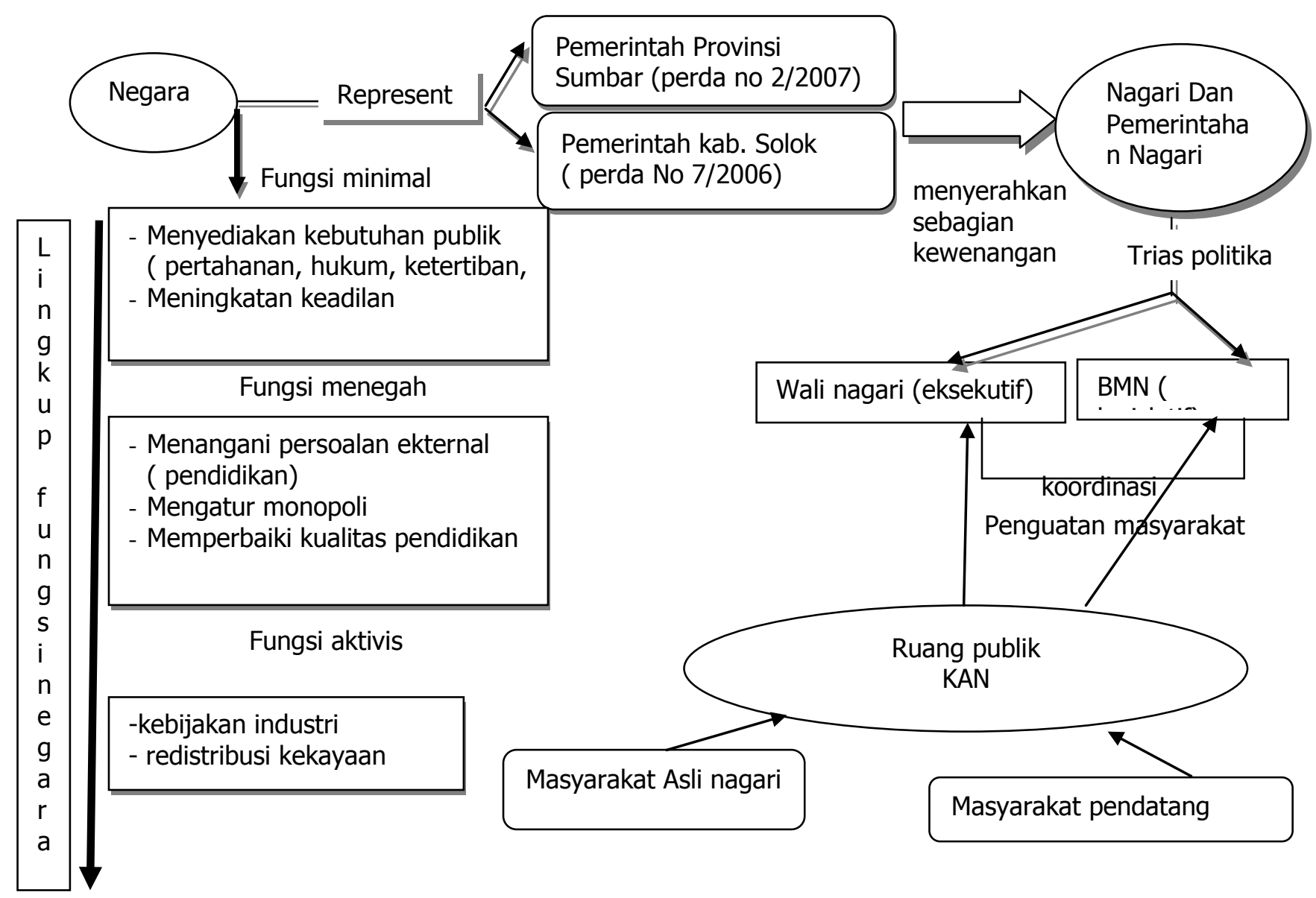

Sumber: Penulis memakai data ruang lingkup fungsi negara dari laporan pembangunan Bank dunia tahun 1997 skema ini diolah dari hasil tulisan dalam Tengku Rika dkk. The state Versus Local Elite Conflict in A Transitional Phase of Democracy. International Journal of Administrative Sciences and Organization. Vol 18, Number 3, September 2011

Gambar 4. Implementasi model Tipe Elite Dan Distribusi Kekuasaan Ketika Negara Menerapkan Intervensinya Pada Pemerintahan Terdepan di Nagari Panyakalan

Dalam teori politik klasik selalu menempatkan masyarakat sipil ${ }^{30}$ dalam fakta bahwa disinilah individu mengenali diri mereka sendiri sebagai makhluk sosial ${ }^{31}$. Mengutip pernyataan De Tocqueville, penguatan masyarakat sipil akan memberikan jalan pada asosiasi politik, melalui masyarakat sipil-lah kelebihan potensial dari sentralisasi negara didalam masyarakat demokratis dapat di kontrol. Masyarakat sipil menyediakan ruang terbentuknya asosiasi yang selama ini didominasi oleh negara. ${ }^{32}$

Berdasarkan perbandingan dari gambar 3 dan 4 penulis membuat sebuah hipotesis bahwa Ketika Pemerintahan Nagari memakai skema pada gambar 3 dengan memaknai pelaksanaan Undang-Undang No. 32 Tahun 2004 intervensi negara (baca: pemerintah daerah) makin jelas terlihat pada pemerintahan terdepan (nagari) hubungan diikat dengan sistem yang masih konsultatif antara negara (baca: pemerintah daerah) dan nagari. Ditambah lagi penguatan masyarakat sipil masih terlihat samar. Negara (baca: pemerintah pusat, dan daerah) memainkan peranannya yang begitu besar dalam ruang lingkup fungsinya sebagai Negara

Ketika penulis merujuk pada konsep elite yang memerintah dengan memakai konsep elitenya Gaetano Mosca ada sedikit revisi dari gambar 3 menuju gambar 4 yaitu penguatan masyarakat sipil sebaiknya diletakan di institusi KAN karena fungsinya yang independen membuat KAN lepas dari segala intervensi negara ( baca: 
pemerinta daerah) dan lembaga lainnya didalam nagari Panyakalan. pendapat ini kemudian penulis "sandingkan"dengan argumen Chandoke bahwa ekspresi masyarakat sipil tidak harus menjadikan Negara (baca: pemerintah daerah).

\section{SIMPULAN}

Penelitian di Nagari Panyakalan, dengan mengambarkan Model Sirkulasi Opini Public Habermas merupakan salah satu "celah" menurut penulis bagi Negara (baca : pemerimtah daerah) untuk masuk pada penerapan model tipe elite dan distribusi kekuasaan, ketika negara mencoba memformat nagari dengan meninggalkan segala bentuk eforia nagari pada masa dahulunya, dengan tujuan menghindari ketenggangan antara elite yang berada pada pusat kekuasaan dengan elite pada tingkat nagari. Hasilnya adalah banyak celah sebenarnya yang bisa dieksplorasi untuk menciptakan sebuah pemerintahan nagari yang "ideal" yang bisa mengakomodir kepentingan banyak pihak, sehingga Konflik politik atas nama pemekaran nagari, konflik antar elite nagari, konflik nagari dengan negara (baca: pemerintah daerah), disfungsi masing masing lembaga di pemerintahan nagari yang selalu dipertanyakan, menurut penulis bisa diminimalisir kalau pemerintah daerah mau berkomitmen bersama sama dengan masyarakat nagari untuk menerapkan model penelitian ini.

\section{DAFTAR PUSTAKA}

Alexis de Tocqueville dalam Sutoro Eko (2006), (bunga rampai) dalam Demokrasi dan Potret Pemilu Lokal 2004 . Yogyakarta : Percik, Pustaka Pelajar.

David Held, (2007), (edisi Ketiga Terjemahan, Abdul Haris), Models of Democracy, Jakarta: Akbar Tanjung Institute.

Gramsci, (1971), Prison Notebooks, Dalam Neera Chandoke. 1995. The State and Civil Society (Exsplorations in Political Theory). Published In India : Sage Publications India Pvt Ltd. Terj: Yuliana- Mohammd Natsin, (2001). Benturan Negara dan Masyarakat Sipil. Yogyakarta: Institut Tafsir Wacana (ISTAWA)
Jurgen Habermas.. (2008). Ruang Publik: Sebuah Kajian Tentang Kategori Masyarakat Borjuis. Cetakan ke 2, Yogyakarta: Kreasi Wacana

Levi Riansyah. Membuka Jalan Partisipasi Kritis Melalui Demokrasi Deliberatif. Dalam Buku seri Demokrasi ke 14. Politik, Partisipasi dan Demokrasi Dalam pembangunan. Malang: Progaram Sekolah Demokrasi Dan Averroes Press. Cetakan I Desember 2009

Max Weber (1946), Essay in Sosiology. New York: Oxford University Press._Dalam Francis Fukuyama. Terj. A.Zaim Rofiqi. (2005). Memperkuat Negara Tata pemerintahan dan Tata dunia Abad 21. Jakarta: PT.Gramedia

Neera Chandoke. 1995. The State and Civil Society (Exsplorations in Political Theory). Published In India : Sage Publications India Pvt Ltd. Terj: Yuliana- Mohammd Natsin (2001). Benturan Negara dan Masyarakat Sipil. Yogyakarta: Institut Tafsir Wacana (ISTAWA).

Pelczynski, ZA. (1984). Introduction: the significance of Hegel's Separation of State and Civil Society. Cambridge : Cambridge University Press. dalam Neera Chandoke. (1995). The State and Civil Society (Exsplorations in Political Theory). Published In India : Sage Publications India Pvt Ltd. Terj: Yuliana- Mohammd Natsin, (2001). Benturan Negara dan Masyarakat Sipil. Yogyakarta: Institut Tafsir Wacana (ISTAWA).

Peraturan Daerah Kabupaten Solok No 7 Tahun 2006 tentang Pemerintahan Nagari

Rika, Tengku dkk. The state Versus Local Elite Conflict in A Transitional Phase of Democracy. International Journal of Administrative Sciences and Organization. Vol 18, Number 3, September 2011.

Strauss dan Crobin (1990), dalam Norman K. Denzin and Yvonna S. Lincoln. Hand Book of Qualitative Research. Sage Publication. Inc 2455 Teller Road Thousand Oaks: California 91320.

USA. 2000 


\section{CATATAN KAKI}

1 Tengku Rika dkk. The state Versus Local Elite Conflict in A Transitional Phase of Democracy. International Journal of Administrative Sciences and Organization. Vol 18, Number 3, September 2011. Page 211-219.

2 Dengan kata lain negara ( baca: pemerintah daerah) mempunyai sifat "memaksa" dalam setiap aturannya. Lihat dalam Max Weber.1946. From Max Weber: Essay in Sosiology. New York: Oxford University Press. Dalam Francis Fukuyama. Terj. A.Zaim Rofiqi. 2005. Memperkuat Negara Tata pemerintahan dan Tata dunia Abad 21. Jakarta: PT.Gramedia . Hal 7-8

${ }^{3}$ Tengku Rika dkk, Op. cit.

${ }^{4}$ Nagari di Sumatera Barat menjadi sebuah kajian yang masih menarik untuk diiskusikan dengan varibel penjelasnya adalah stratifikasi sosial dan model kekerabatan serta sistem politik (kelarasan koto piliang dan bodi chaniago) yang sangat berbeda menjadikan nagari sangat kaya dengan analisis sejarah transisi demokrasinya, model partisipasi dan model intervensi Negara yang menyertai perjalanannnya.

${ }^{5}$ Alexis de Tocqueville dalam Sutoro Eko ( 2006) (bunga rampai) dalam Demokrasi dan Potret Pemilu Lokal 2004 . Yogyakarta : Percik, Pustaka Pelajar. Hal 25-26.

6 Jurgen Habermas. Cetakan ke 2. 2008. Ruang Publik: Sebuah Kajian Tentang Kategori Masyarakat Borjuis. Kreasi Wacana : Yogyakarta . lihat juga dalam tulisannya Levi Riansyah. Membuka Jalan Partisipasi Kritis Melalui Demokrasi Deliberatif. Dalam Buku seri Demokrasi ke 14. Politik, Partisipasi dan Demokrasi Dalam pembangunan. Malang: Progaram Sekolah Demokrasi Dan Averroes Press. Cetakan I Desember 2009

7 Strauss dan Crobin 1990 dalam Norman K. Denzin and Yvonna S. Lincoln. Hand Book of Qualitative Research. Sage Publication. Inc 2455 Teller Road Thousand Oaks: California 91320. USA. 2000. hal 351

${ }^{8}$ Informan dalam penelitian ini adalah

a. Wali Nagari Panyakalan (eksekutif)

b. Ketua Badan Musyawarah Nagari /BMN ( legislatif)

c. Ketua Kerapatan Adat Nagari ( Yudikatif)

d. Kepala Jorong sebagai Wakil Nagari di Administrasi paling bawah ( ada empat kepala jorong)

e. Kasi/kaur Pemerintahan Nagari, Aset

f. Sekretaris Nagari

g. Tokoh masyarakat pendatang

h. Tokoh masyarakat asli nagari

${ }^{9}$ Dalam Perda kabupaten solok No 7 tahun 2006 tentang Pemerintahan Nagari pasal 15 ayat 3 calon wali nagari sebagaimana dimaksud dalam ayat 2 yang telah ditetapkan sebagai wali nagari berhak dipilih dan diumumkan kepada masyarakat di tempat umum sesuai dengan adat istiadat setempat oleh panitia pemilihan.

${ }_{10}$.......... Khusus di nagari panyakalan, mekanisme tupoksi dan wewenang antara pemerintah nagari dan kecamatan saja selalu ada tumpang tindih... dalam aturan peraturan daerah, wali nagari bertanggung jawab pada bupati, sehingga dalam hal ini selalu menampikan fungsi kecamatan didalamnya, karena kecamatan hanya berfungsi sebagai koordinasi saja. Istilahnya pejabat lintas batas saja, tanpa ada aturan yang mengikat...... (Wawancara dengan Wali Nagari Panyakalan pada tanggal 12 Desember 2012 di kantor Wali Nagari panyakalan).

${ }^{11}$ Konsep demokrasi deliberatif tidak saja berada pada ranah epistimologi, namun dari pada itu sangat kaya dengan solusi strategis atas berbagai masalah pada demokrasi modern..... dan dalam Levi Riansyah. Membuka Jalan Partisipasi Kritis Melalui Demokrasi Deliberatif. Dalam Buku seri Demokrasi ke 14. Politik, Partisipasi dan Demokrasi Dalam pembangunan. Malang: Program Sekolah Demokrasi Dan Averroes Press. Cetakan I Desember 2009. Hal 3.

12 baca juga David Held, 2007, (edisi Ketiga Terjemahan, Abdul Haris), Models of Democracy, Akbar Tanjung Institute: Jakarta, hal $272-280$

${ }_{13}$ Pembagian kekuasaan menurut Jurgen Habermas dimana tiga kekuasaan ini adalah sirkulasi komunikatif ( Diadopsi dari Hardiman dalam Levi Riansyah, 2009: Hal 8 ) dalam hal ini peneliti mengadopsinya untuk mencari solusi ketimpangan kewenangan antara pemerintah nagari di Panyakalan dan Pemerintah Kabupaten Solok

${ }^{14}$ Yang di pahami sebagai elite nagari dalam penelitian ini adalah ninik mamak, alim ulama, cadiak pandaii dan pemangku adat dalam nagari.

${ }_{15}$ Sumber data Primer Tugas dan fungsi Wali Nagari Panyakalan Tahun 2011-2012.

${ }^{16}$ Instruksi wali nagari hanya sebatas kewajiban yang ditujukan kepada masyarakat nagari yaitu salah satunya masalah goro bersama.

17 Jurgen Habermas.... Op.Cit. Hal 309 dan lihat juga Levi Riansyah. Membuka Jalan Partisipasi Kritis Melalui Demokrasi Deliberatif. Dalam Buku seri Demokrasi ke 14. Politik, Partisipasi dan Demokrasi Dalam pembangunan. Malang: Progaram Sekolah Demokrasi Dan Averroes Press. Cetakan I Desember 2009

18 "...Selama ini fungsi KAN dalam nagari hanya mengurus masalah sako dan pusako serta permasalahan pada anak kemenakan saja dan sedapat mungkin menyelesaikan dalam interen suku mereka..." ( wawancara dengan Ketua KAN Nagari Panyakalan pada tanggal 12 Desember 2012 di Kantor wali Nagari Panyakalan)

${ }^{19}$ Rekapitulasi wawancara dengan Ketua KAN dan ditriangulasi oleh peneliti kepada ketua BMN pada tanggal 13 Desember 2012.

20 Dalam Levi Riansyah. Membuka Jalan Partisipasi Kritis Melalui Demokrasi Deliberatif. Dalam Buku seri Demokrasi ke 14 . Politik, Partisipasi dan Demokrasi Dalam pembangunan. Malang: Progaram Sekolah Demokrasi Dan Averroes Press. Cetakan I Desember 2009. Hal 26.

${ }^{21}$ Dalam Levi Riansyah.... Op. Cit...hal 24.

22 Habermas mengatakan ruang publik politis penekanannya disini adalah bukan dalam bentuk public politis didalam konteks Negara hukum, istilah politis merupakan penanda atas ruang publik pada bingkai tindakan komunikatif yaitu pada diskursus praktis, artinya ruang publik politis adalah sebuah ruang memungkin semua orang untuk dapat mengkasesnya

${ }^{23}$ Maksudnya adalah Koto Piliang sangat Aristokrasi dan Bodi Chaniago sangat Egaliter, maka Lareh nan Bunta akan memakai dua sistem politik ini

${ }^{24}$ Diadopsi dari Model yang dilukiskan Hardiman dalam Levi Riansyah, 2009: Hal 27

${ }^{25}$ Dalam Levi Riansyah....Op.Cit. hal 26-27 
${ }^{26}$ netral yang maksud disini adalah tidak memisahkan kepentingan antara masyrakat asli dan pendatang

${ }^{27}$ Lihat dalam Tengku Rika dkk. The state Versus Local Elite Conflict in A Transitional Phase of Democracy. International Journal of Administrative Sciences and Organitation. Vol 18, Number 3, September 2011. Page 211-219.

${ }^{28}$ ibid

29 Dalam Tengku Rika dkk. The state Versus Local Elite Conflict in A Transitional Phase of Democracy. International Journal of Administrative Sciences and Organization. Vol 18, Number 3, September 2011. Hal 215

${ }^{30}$ Pelczynski mengatakan Masyarakat sipil dalam pengertian ini adalah adalah sebuah arena manusia modern secara sah memenuhi keinginan pribadinya dan mengembangkan sifat- sifat individunya. Pelczynski, ZA. (1984) . introduction: the significance of Hege/'s Separation of State and Civil Society. Cambridge : Cambridge University Press. Hal 1-13 dalam Neera Chandoke. 1995. The State and Civil Society (Exsplorations in Political Theory). Published In India : Sage Publications India Pvt Ltd. Terj: Yuliana- Mohammd Natsin. Benturan Negara dan Masyarakat Sipil. Yogyakarta: Institut Tafsir Wacana (ISTAWA). 2001.

${ }^{31}$ Neera Chandoke. 1995. The State and Civil Society (Exsplorations in Political Theory). Published In India : Sage Publications India Pvt Ltd. Terj: Yuliana- Mohammd Natsin. Benturan Negara dan Masyarakat Sipil. Yogyakarta: Institut Tafsir Wacana (ISTAWA). 2001. Hal 40.

32 Seperti yang dikatakan oleh Gramsci dalam Prison Notebooks dimana diatara struktur ekonomi dan Negara yang mengatur dan memaksa terdapat masayarakat sipil didalammnya (1971:208-209.) Dalam Neera Chandoke. 1995. The State and Civil Society (Exsplorations in Political Theory). Published In India : Sage Publications India Pvt Ltd. Terj: Yuliana- Mohammd Natsin. Benturan Negara dan Masyarakat Sipil. Yogyakarta: Institut Tafsir Wacana (ISTAWA). 2001. 